Discussion Paper No. 780

\title{
TRADE AND INEQUALITY \\ WITH LIMITED LABOR MOBILITY: \\ THEORY AND EVIDENCE FROM CHINA
}

\author{
Muqun Li \\ Ian Coxhead
}

June 2010

The Institute of Social and Economic Research Osaka University

6-1 Mihogaoka, Ibaraki, Osaka 567-0047, Japan 
Trade And Inequality With Limited Labor Mobility: Theory And Evidence From China*

Muqun Li and Ian Coxhead

\begin{abstract}
Does globalization increase inequality in developing countries, and if so, how? In a theoretical model of a regionally heterogeneous economy, we show how different regional rates of technical progress due to trade and FDI interact with constraints to unskilled labor mobility. As favored regions benefit more from trade, their growing demand for skills drains skilled workers from disadvantaged areas, and average incomes in the former grow faster than in the latter. Moreover, this unbalanced regional growth may also raise inequality within each region. It could even reduce absolute income per capita in the less favored region. We test these predictions with Chinese data from the Open Door era. Results confirm that different regional growth rates have increased both interregional and intraregional inequality. Moreover, growth of skills-based export industries in coastal regions is associated, other things equal, with lower incomes for the poor in inland provinces.
\end{abstract}

JEL codes: F16, O15, R1.

Key words: trade, investment, wage premium, migration, inequality, China

\footnotetext{
* Li: Samsung Economic Research Institute, 25/F China Merchants Tower, No.118, Jian Guo Lu, Chao Yang District, Beijing, China 100022. Email: muqunli@gmail.com. Coxhead: University of Wisconsin-Madison, 413 Taylor Hall, 427 Lorch St., Madison, WI 53706. Email: coxhead@wisc.edu. We thank seminar participants at the University of Wisconsin-Madison and Waseda University for comments on earlier drafts. Coxhead thanks the Institute of Social and Economics Research at Osaka University for hosting a sabbatical research leave during which this paper was extensively revised. A mathematical appendix to this paper (PDF format) can be accessed at http://tinyurl.com/LiCoxheadAppendix.
} 
1 Introduction

Does trade increase inequality in developing countries? According to standard theory, for low-income countries with comparative advantage in less skill-intensive products, trade lowers the relative prices of skill-intensive imported goods, and along with them the skill premium (the skilled-unskilled wage ratio). Thus trade, by raising the relative demand for low-skill workers, should reduce both poverty and inequality. However, many empirical studies show that expanded trade is associated with higher wage inequality (Hanson and Harrison 1995; Robbins 1996; Wood 1997; Goldberg and Pavcnik 2004). These challenges to standard theory have generated a number of theoretical responses, discussed below.

At the same time, inequality is rarely unidimensional, so a single nationwide skill premium may not suffice as a measure of inequality. The standard model assumes domestic factor mobility, but empirical studies show clearly that the benefits of trade openness don't always spread uniformly within an economy. Studies in Mexico and China, for example, show that isolated regions lag behind areas better positioned for trade (Hanson 2004; Hale and Long 2008; Candelaria et al. 2009).

It follows that domestic labor markets are central to both growth and inequality outcomes from trade. Industries are never uniformly distributed in space, so structural changes induced by trade and specialization require physical movement of factors, especially labor. Barriers to labor mobility thus make it difficult for the poor (who own mainly low-skill labor) to exploit opportunities created by trade. Understanding how trade affects inequality helps us not only to understand inequality itself, but also how to design policy to mitigate adjustment costs borne by the poor.

No country exemplifies the interactions of trade, demand for skills, and geographic labor market rigidities better than China. With rapidly growing foreign trade, China has had rapid growth and poverty alleviation, but also large increases in inequality. From 1988-95 the Gini coefficient of earnings rose by eight percentage points (Knight and Song 2003; Wang and Shi 2006). Regional incomes have also diverged, and in particular, the gap between coastal and interior provinces (Jian et al. 1996; Zhang and 
Zhang, 2003). China is now on a dual track, with a prosperous and fast-growing coastal region, a poor interior growing much more slowly, and poverty is more severe in inland than coastal China (Wan and Zhang 2008).

Why do spatial disparities arise? As China integrates with global markets, the comparative advantage of its regions needs to be evaluated in a global context. Coastal regions enjoy comparative advantage in proximity to the world market and have access to a large pool of well-educated labor. As a result, they have attracted far more FDI and generated more trade volume than have inland provinces.

Why do spatial disparities persist? Partly, because domestic factors are not equally mobile. Internal barriers to labor mobility are especially significant, and apply differentially to labor of differing skills. In China these include legal impediments based on the hukou (household registration) system as well as less formal discrimination against migrants from inland provinces. Faster growth in richer regions may have reduced growth in poorer regions by attracting capital and skilled workers, leaving behind unskilled workers with fewer complementary resources. Differential labor mobility may have exacerbated differences in regional comparative advantage despite a uniform national trade policy.

So-called New Economic Geography models explain the location of production within an economy by showing how internal trade costs lead to regional divergence (Fujita et al 1999; Krugman and Venables 1995; Monfort and Ypersele 2003). But these models assume that each region has access to the same technology and labor endowments. This may be good for explaining integration among similar economies such as EU states, but is less helpful for more heterogeneous developing economies. Other models have explained rising wage inequality associated with North-South trade (Feenstra and Hanson 1996; Zhu and Trefler 2005), but these models do not allow for regional heterogeneity within either North or South. To explain both wage inequality and interregional disparities requires more detail. In this paper we address this by supposing that South has two regions, Coast and Inland, each with different labor and skills endowments and production technologies. There is a continuum of goods 
ranked by skill-intensity; each good is produced in the region that is most efficient at producing it, and the rest of the world imports it from that region. By assumption, North produces the most skill-intensive goods; Coast has intermediate skill-intensity, Inland supplies unskilled-intensive goods. Trade and FDI offer opportunities for increased production and productivity growth. Coast's catch-up in technology with North attracts its less skill-intensive production, so firms in Coast offer a higher wage premium. Within South, if skilled labor can move freely but unskilled labor cannot, faster growth in Coast may attract both production and skilled labor from Inland. Inland now has fewer skilled workers, lower growth, and a higher wage premium. Thus trade may raise inequality both within and between the two regions. The empirical part of our paper uses Chinese data to test these predictions.

Our model differs from earlier work in that it allows for spatial heterogeneity within South, and for differential mobility of skilled and unskilled workers. In other departures, we assume neither that countries share the same technology nor that regions within a country have equal skill endowments. Because of this, we can resolve wage inequality and income inequality simultaneously. This paper is the first, to our knowledge, to study the relationship between trade and multidimensional inequality in a low-income country.

Our work builds on the seminal contribution of Zhu and Trefler 2005 (hereafter ZT). In ZT, initial technology and endowment differences determine that North produces and exports skill-intensive goods, while South produces and exports low-skill goods. Southern technology catch-up causes production of North's least skill-intensive goods to move to South. This raises relative demand for skills, and thus wage inequality, in both economies. As noted, however, this framework does not admit different sub-national responses of the skill premium and of economic structure to trade; therefore, it makes no prediction about regional inequality within the South; nor does it capture general equilibrium mechanisms and labor market operations within the South. Neither of these are trivial problems. 
Our goal is to capture mechanisms linking trade and technology to wages and economic structure when South consists of two (or potentially more) heterogeneous regions. Countries and regions in our model have different factor endowments and technology; this admits regional growth differences within South. We are also able to study the influence of factor market segmentation on this process. In section 2 of this paper we develop an analytical model and link theoretical predictions to empirical work. In section 3 we describe data, model specification and empirical results. In section 4, we draw conclusions.

\section{Model}

For ease of comparison we use ZT's notation wherever feasible. There are two factors of production, unskilled labor $(L)$ and skilled labor $(H)$. These are used to produce a continuum of goods $z$, ranked in increasing order of skill intensity. Production functions are neoclassical, with strict quasi-concavity, constant returns to scale, and continuous derivatives. There are no factor intensity reversals. Goods markets are perfectly competitive, and thus in equilibrium profit is zero.

Production occurs in (relatively) skill-abundant North and skill-scarce South. South has two regions, skill-scarce Inland and skill-abundant Coast. In China, barriers to labor mobility persist despite trade reforms; we stylize this by initially assuming no labor movement between Inland and Coast.

Let $L_{k}(z)$ and $H_{k}(z)$ be the unskilled and skilled labor requirements for producing one unit of good $z$ in region $k(k=N, C, I)$. Let $w_{j k}$ be the wage of factor $j(j=L, H)$ in region $k$. Let $\omega_{k}=w_{H k} / w_{L k}>1$ be the skilled-unskilled wage ratio in region $k$. North is the most skill-abundant country, so $\omega_{N}<\omega_{C}<\omega_{I}$. Furthermore, we assume

$$
w_{H I} \geq w_{H C}>w_{H N}>w_{L N}>w_{L C} \geq w_{L I}
$$

Given prices and wages, a firm producing variety $z$ in region $j$ maximizes:

$$
\max _{L_{j}(z), H_{j}(z)} P(z) f\left(L_{j}(z), H_{j}(z)\right)-\left(w_{L j} L_{j}(z)+w_{H j} H_{j}(z)\right)
$$


where $P(z)$ is the price of variety $z$. With constant returns to scale and free entry, firms bid for workers until no firm earns a strictly positive profit. Therefore, $C_{j}\left(w_{H j}, w_{L j}, z, t\right)$, the unit cost function for $z$ in region $j$, must equal $P(z)$. Finally, $n$ stands for total varieties available, and $t$ denotes time and captures all factors other than wage that affect unit costs—-for instance technology level or infrastructure in each region. Costs are thus written

$$
C_{j}\left(w_{H j}, w_{L j}, z, t\right)=w_{L j} L_{j}(z)+w_{H j} H_{j}(z)
$$

Here, $L_{j}(\mathrm{z})$ and $H_{j}(\mathrm{z})$ represent the optimal quantities of unskilled and skilled labor to produce one unit of variety $z$, given the endowments and technology available in each region.

We assume for simplicity that goods can be costlessly shipped across countries and regions.

Perfect competition exists for good z produced in this region, so the zero profit condition implies

$$
P_{j}(z)=w_{L j} L_{j}(z)+w_{H j} H_{j}(z)
$$

As with other technology-oriented theories of trade (Dornbusch et al. 1977; Krugman 1982), our model allows for international technology differences (for succinctness, in what follows we include $t$ only when necessary). We assume a Ricardian pattern of comparative advantage, i.e.

$$
\frac{\partial C_{N}(., ., z) / C_{S}(., ., z)}{\partial z} \leq 0 \quad \text { and } \quad \frac{\partial C_{C}(., ., z) / C_{I}(., ., z)}{\partial z} \leq 0
$$

for all $z$, where $C_{S}(., ., z)=\min \left[C_{C}(., ., z), C_{I}(., ., z)\right]$. According to (3), North is the technology leader in all production, especially in more skill-intensive goods. Inland lags in every field, but has comparative advantage in least skill-intensive goods; Coast is intermediate.

Lemma 1: Endowment-based comparative advantage (inequality 1) and Ricardian comparative advantage (inequality 4) together imply

$$
\frac{\partial C_{N}\left(w_{H N}, w_{L N}, z\right) / C_{S}\left(w_{H S}, w_{L S}, z\right)}{\partial z}<0 \quad \text { and } \quad \frac{\partial C_{C}\left(w_{H C}, w_{L C}, z\right) / \partial C_{I}\left(w_{H I}, w_{L I}, z\right)}{\partial z}<0
$$


for all $\left(w_{H j}, w_{L j}\right)$, that is, the North has a comparative advantage in skill-intensive goods, and Coast is good at intermediate skill-intensive production.

Inequality 3, Lemma 1 and the zero profit conditions together imply that North produces and exports the most skill-intensive goods, Coast produces and exports intermediate skill-intensive goods, and the least skill-intensive goods are all produced in Inland. We define the marginal goods, $z_{i}, i=1,2$ by $P_{N}\left(z_{2}\right)=P_{S}\left(z_{2}\right), \quad P_{C}\left(z_{1}\right)=P_{I}\left(z_{1}\right)$. We can think of North as producing newly developed goods that require high skill input. The high cost of skills, lower level of technical know-how, and poor infrastructure in South all inhibit skill-intensive production. But as products mature, the production process becomes standardized and routine and less-skilled labor can play a larger role. With technology diffusion, some production can then be outsourced to South to take advantage of lower costs.

\section{Equilibrium}

Consumers supply labor inelastically and have identical preferences over a continuum of differentiated consumption goods. The utility function is assumed to be of the form:

$$
U_{i}=\int_{0}^{\bar{z}} \alpha(z) \ln x_{i}(z) d z
$$

where $x(z)$ stands for the amount of variety $z$ demanded by the representative consumer. Consumer $\mathrm{i}$ maximizes utility subject to a budget constraint $E_{i}$, equal to their labor income, which depends on skill status and on country or region of origin. The budget constraint of an unskilled worker in the North, for example, is $\int_{0}^{\bar{z}} P(z) x(z) d z=w_{L N}$, and analogous constraints exist for other types of worker.

The utility function implies that consumers have a strong preference for variety. Individual demand for variety $z, x(z)$, obtained by maximizing utility with respect to the quantity of $z$ consumed subject to the budget constraint $x_{i}(z)=\alpha(z)[E / P(z)]$, so $\alpha(z)$ is a budget share. Let $Y_{i}$ be aggregate income in country $I$; then worldwide demand is 


$$
x(z)=\alpha(z) \frac{Y_{N}+Y_{C}+Y_{I}}{P(z)} .
$$

We assume competitive markets and zero shipping costs, so $P(z)$ is the price faced by both consumers and producers, and is denoted as follows. For goods produced in North, i.e. $z \geq z_{2}$, $P(z)=P_{N}(z)$; for goods produced in Coast $\left(z_{2}>z \geq z_{1}\right), P(z)=P_{C}(z)$; and for goods produced in Inland $\left(z<z_{1}\right), P(z)=P_{I}(z)$. This gives goods market equilibrium.

In the labor market, $H_{j}$ and $L_{j}, j=N, C, I$, are skilled and unskilled labor endowments, and each region's relative skills endowment is $h_{j}=H_{j} / L_{j}$. Labor supply is fixed, so the resource constraints for skilled and unskilled labor in the North are given by

$$
\int_{z_{2}}^{\bar{z}} x(z) H_{N}(z) d z=H_{N} \text { and } \int_{z_{2}}^{\bar{z}} x(z) L_{N}(z) d z=L_{N}
$$

where $H_{N}(z)$ and $L_{N}(z)$ are skilled labor and unskilled labor used in production of good $z$ in North. We define North's excess demand for skilled labor relative to unskilled labor, $N\left(z_{2}\right)$, by

$$
N\left(z_{2}\right) \equiv \int_{z_{2}}^{\bar{z}}\left[x(z) H_{N}(z) / H_{N}\right] d z-\int_{z_{2}}^{\bar{z}}\left[x(z) L_{N}(z) / L_{N}\right] d z
$$

In the same fashion, $S_{I}\left(z_{1}\right)$ and $S_{C}\left(z_{2}\right)$ are excess demands for Inland and Coast:

$$
\begin{aligned}
& S_{I}\left(z_{1}\right)=\int_{0}^{z_{1}}\left[x(z) H_{I}(z) / H_{I}\right] d z-\int_{0}^{z_{1}}\left[x(z) L_{I}(z) / L_{I}\right] d z \\
& S_{C}\left(z_{2}\right)=\int_{z_{1}}^{z_{2}}\left[x(z) H_{C}(z) / H_{C}\right] d z-\int_{z_{1}}^{z_{2}}\left[x(z) L_{C}(z) / L_{I}\right] d z .
\end{aligned}
$$

Relative labor demand can then be rewritten as follows (see appendix for details):

$$
\begin{aligned}
& N\left(z_{2}\right)=\frac{Y_{N}+Y_{C}+Y_{I}}{w_{L N} L_{N}} \int_{z_{2}}^{\bar{z}} \alpha(z) \frac{h_{N}(z)-h_{N}}{1+\omega_{N} h_{N}(z)} d z=0 \\
& S^{C}\left(z_{1}\right)=\frac{Y_{N}+Y_{C}+Y_{I}}{w_{L C} L_{C}} \int_{z_{1}}^{z_{2}} \alpha(z) \frac{h_{C}(z)-h_{C}}{1+\omega_{C} h_{C}(z)} d z=0
\end{aligned}
$$




$$
S^{I}\left(z_{1}\right)=\frac{Y_{N}+Y_{C}+Y_{I}}{w_{L I} L_{I}} \int_{0}^{z_{1}} \alpha(z) \frac{h_{I}(z)-h_{I}}{1+\omega_{I} h_{I}(z)} d z=0 \text {. }
$$

The final equilibrium condition concerns trade. We assume balanced trade between each area and the rest of the world. Thus for North:

$$
T B_{N}=\left(Y_{C}+Y_{I}\right) \int_{z_{2}}^{\bar{z}} \alpha(z) d z /\left(Y_{N} \int_{0}^{z_{2}} \alpha(z) d z\right)=1
$$

in which the numerator is world demand for goods produced in North and the denominator is North's import demand. Similarly, for Inland,

$$
T B_{I}=\left(Y_{N}+Y_{C}\right) \int_{0}^{z_{1}} \alpha(z) d z /\left(Y_{I} \int_{z_{2}}^{\bar{z}} \alpha(z) d z\right)=1,
$$

and when both these equalities hold, Coast's trade is also balanced by Walras' Law. In contrast with ZT, each Southern region has two trading partners. In the absence of transfers or factor flows, each region must have balanced trade. This allows us to trace out the otherwise unobservable interaction between Southern regions. The exact expressions are provided in the appendix; these show that when labor markets clear and trade is balanced, equilibrium can be fully represented by the vector of relative wages and marginal goods $\left(\omega_{N}, \omega_{C}, \omega_{I}, z_{1}, z_{2}\right)$ (Dornbusch et al. 1980; Zhu and Trefler 2005).

\section{Technical change}

The technology level is a determinant of each region's economic structure. Restructuring—for example through trade and FDI — may be associated with different speeds of technical change, a subject with a long tradition in the analysis of trade and welfare (e.g., Dixit and Norman 1980). However, this literature seldom discusses effects on relative factor prices, which are the main focus of this paper. We define Southern technology catch-up either as technology spillover from North or as cost-reducing process innovations. We assume that technical change is exogenous and uses no real resources. As in Vernon (1966), new products are first produced in North, but once the manufacturing method is standardized, South can easily imitate and take advantage of its cheaper labor to begin production. 
In the age of globalization, however, barriers to the flow of technical know-how from technological leaders to followers have been greatly reduced. Trade provides new sources of technical progress (Grossman and Helpman 1991; Rivera-Batiz and Romer 1991). Major obstacles, such as information asymmetries and North-South factor proportion differences, make technology acquisition a complex process, and the speed of technology diffusion varies across countries and regions. Among the factors that facilitate technology adoption, human capital availability is well documented. Southern costreducing innovation occurs as Southern labor masters technological know-how.

We define productivity gain in region $j$ by $\phi_{j}(z, t) \equiv \frac{\partial \ln C_{j}\left(w_{H j}, w_{L j}, z, t\right)}{\partial t}$. From the definition of efficiency improvement, we know $\phi_{j}(.,$.$) is always non-positive. So by definition, technological$ catch-up in Coast is defined by $\phi_{N}(z, t)-\phi_{C}(z, t)>0$; otherwise, we say that Coast lags behind North. Similarly, $\phi_{C}(z, t)-\phi_{I}(z, t)<0$ implies that technical progress in Coast outpaces that in Inland. Lemma 2: As production range increases in one region, both skilled and unskilled wages in that region increase, for a given technology.

Proposition 1: When Coast catches up with North, and when Inland has a slower rate of technical progress than Coast, some skill-intensive goods production migrates into Coast from North, and Inland loses its most skill-intensive goods to Coast. Wage inequality in North increases; that in Inland decreases. Wage inequality in Coast can go either way.

Proposition 2: When Coast catches up with North, and Inland has slower technical progress compared to that of Coast, returns for both skilled and unskilled labor decrease in Inland, while both unskilledand skilled-labor wages increase in Coast. Regional inequality also increases.

Proofs: see appendix.

When there is balanced technical progress within South, we return to the ZT economy. But as long as technical progress occurs at different rates in Inland and Coast, it creates extra effects. For 
instance, if Inland lags Coast in productivity growth, then at constant wages Inland becomes less productive relative to Coast. Therefore, slower income growth in Inland results in a trade surplus for this area with Coast. To restore trade balance requires Inland to produce less, while Coast needs to increase its variety of goods. This leads to a rise in $\mathrm{z}_{2}$, and a fall in $\mathrm{z}_{1}$.

When wages are permitted to change, slower technical progress in Inland results in a lower regional skill premium, while wage inequality in Coast is reduced by that region's expansion into less skill-intensive production. Thus faster technical progress in Coast compared to the other regions has two opposing effects on its wage inequality. Technical progress and expanded production raise both skilled and unskilled wages, and the relative wage outcome depends on which effect dominates. In Inland, by contrast, both wage changes are indeterminate, so technical progress and reduced production lines have opposing effects (in the special case of a lack of technical progress, both wages decrease). But in any case, returns to both types of labor rise faster in Coast than in Inland.

\section{Labor mobility}

Up to this point, our model has departed from its predecessors only in the regional decomposition of the South economy. We now partially relax the restriction of labor immobility by allowing skilled labor to move freely within South. This asymmetry in relative labor mobility has robust empirical support. Within China, most permanent migrants are skilled workers. Their moves are facilitated by a special residence certificate known as the "blue stamp hukou," introduced in 1992. The criteria for obtaining a blue stamp hukou include a large investment or home purchase, as well as age, education, and skills. Most low-skill or rural migrants are ineligible for this type of certificate, or cannot afford it. Thus, despite large numbers of unskilled internal migrants, skilled workers move in proportionally far greater numbers because of the relative ease with which they can relocate themselves and their families.

Returning to the model, we now assume free mobility of skilled labor within the South economy. So $H_{C}+H_{I}=H_{S}$, and we define $H_{C} H_{S}=\eta$, i.e., the proportion of skilled labor in Coast. Now, a 
technology shock in one region has two kinds of effect: it causes production to move as before, but it also induces skilled labor movement, thereby also altering regional factor endowments. Both effects alter regional incomes and thus their import demands: for example, when skilled labor moves out of Inland (i.e, $\eta$ rises), import demand decreases because of a reduction of local population and income, and in order to keep trade balanced, Inland's exports also decrease. These changes result in new trade balance conditions, shown in full in the appendix.

Also, with skilled labor mobile the labor market clearing condition in South becomes

$$
\int_{0}^{z_{1}} \frac{Y_{N}+Y_{C}+Y_{I}}{w_{L I}} \alpha(z) \frac{1 / L_{I}(z)}{1+\omega_{I} h_{I}(z)} H_{I}(z) d z=(1-\eta) H_{S},
$$

and with all else constant, $\omega_{I}$ is decreasing in $1-\eta$. Thus Inland wage inequality is a decreasing function of the number of skilled workers in that region.

The relative demand for skilled labor in Inland is:

$$
S^{I}(z) \equiv \int_{0}^{z_{1}}\left[\alpha(z) \frac{Y_{N}+Y_{I}+Y_{C}}{w_{H I} H_{S}(1-\eta)\left(l_{I}(z) / \omega_{I}+1\right)}\right] d z-\int_{0}^{z_{1}}\left[\alpha(z) \frac{Y_{N}+Y_{I}+Y_{C}}{w_{H I} L_{S}\left(l_{I}(z) / \omega_{I}+1\right)}\right] d z=0 .
$$

Similarly, in Coast,

$$
S^{C}\left(z_{1}\right) \equiv \int_{z_{1}}^{z_{2}}\left[\alpha(z) \frac{\left(Y_{N}+Y_{I}+Y_{C}\right) L_{C} / \eta H_{S}}{w_{H C} \eta H_{S}\left(l_{C}(z) / \omega_{C}+1\right)}\right] d z-\int_{z_{1}}^{z_{2}}\left[\alpha(z) \frac{Y_{N}+Y_{I}+Y_{C}}{w_{H C} L_{C}\left(l_{C}(z) / \omega_{C}+1\right)} l_{C}(z)\right] d z=0
$$

The asymmetric treatment of labor mobility is a substantial step away from earlier North-South models. It introduces a new channel for trade and trade-related phenomena to influence income distribution. As productivity rises in Coast due to trade and/or FDI, each region undergoes both a change in production structure — with Inland losing capacity to produce its most skill-intensive goods—and a change in relative factor endowments, which further widens the technological gap.

Proposition 3: As Coast catches up with North, and Inland has slower technical progress than Coast, 
some skill-intensive production moves from North to Coast, and Inland loses its most skill-intensive goods to Coast. Wage inequality rises in both North and Inland, while that in Coast can go either way. Proposition 4: When Inland has slower technical progress than Coast, unskilled wages in Coast increase more than those of Inland. Skilled wages in South increase, and regional inequality also increases. Proofs: see appendix.

Propositions 3 and 4 tell us the following. First, holding endowments constant, the situation is exactly as in Proposition 1, i.e., Coast's production range expands and Inland's shrinks. Wage inequality in Inland falls; that for Coast may rise or fall, but we know for certain that $d \omega_{I} / d t>d \omega_{C} / d t$. Second, the rising skill premium draws Inland skilled labor to Coast, thereby reducing relative wages in Coast. The net effect on inequality is ambiguous. In Inland, the relative demand for skilled labor decreases, as does the relative wage. Outflows of skilled labor boost the skill premium in this region until skilled wages equalize in both Coast and Inland. So the skill premium rises in both Coast and Inland.

Thus far we have abstracted from the consequences of factor mobility on changes in economic structure. The inflow of skilled labor helps Coast to expand production at the expense of both Inland and North. In turn, demand for both types of labor decreases in Inland, while demand for labor in Coast increases even more. This second-round effect of labor mobility causes both skilled and unskilled wages to fall in Inland and to rise in Coast. In equilibrium, we know that inequality in Inland must be higher than that of Coast, and unskilled laborers in Inland certainly earn less than those in Coast.

\section{EMPIRICS}

In this section we test the foregoing analytical predictions using data from China. We test only propositions 3 and 4, the cases in which skilled workers are mobile but unskilled workers are not. Several features of China make this highly relevant. First, it is a very large country whose provinces have widely varying geography, technology levels and skill endowments. Second, as mentioned, there is restricted labor mobility, especially for those with few skills. Third, after opening to trade, regions 
have had different access to FDI and its associated productivity-enhancing technologies and networks. Thus, if a worker with skill level $s_{\mathrm{i}}$ in province j earns wage $w_{i}^{j}=m^{j}\left(s_{i}\right), m^{j}($.$) is a provincial function$ that maps labor skills into wages. This $m^{j}($.$) is itself a function of export composition, relative skill$ stock and other province-specific characteristics. Our model predicts that intra-province inequality increases with z, its marginal good: $d \omega_{s}^{i} / d z_{j}>0, j=I, C$. An increase in z is associated with higher wages for both skilled and unskilled workers: $d w_{j} / d z>0, j=L, H$. On the other hand, technical progress (lower unit costs) leads to higher $\mathrm{z}$, and higher $\mathrm{z}$ is associated with higher wage inequality, so $d \omega_{j} / d C_{j}>0$.

\section{Data and estimation methods}

The database covers 29 provinces over 1993-2005 (data for Tibet and Chongqing are unavailable). There are inevitably some compromises to be made between ideal and available datasets. Ideally we would have measures of skilled and unskilled wages $\left(w_{L j}^{t}\right.$ and $\left.w_{H j}^{t}\right)$ in province $j$ and year t. Then intraprovincial wage inequality in province $j$ would be $\omega_{j}^{t}=w_{H j}^{t} / w_{L j}^{t}$, and interprovincial inequality at time $\mathrm{t}$ between provinces i and j would be $w_{L i}^{t} / w_{L j}^{t}$, as in our analytical model. Unfortunately, provincial wage data by occupation are incomplete. Instead, we use the Gini coefficient of disposable income per worker to capture inequality. Using the Gini as a proxy for the skill premium has potential problems: the relation between the two is nonlinear, and could even be non-monotonic. However, a review of trends in provincial human capital stocks reveals relatively smooth changes over time. Therefore, nonmonotonicity issues should not greatly affect the dataset.

There are other limitations too. First, the urban labor force survey is restricted to households holding urban hukou, and so excludes migrants working illegally in cities. The survey also excludes rural wage workers. However, since most wage employment is in urban areas and most wage-workers are urban residents, the data should nonetheless capture major changes in wage inequality. Second, 
working hours are not reported, precluding construction of hourly wage rates. Third, we must treat different workers from the same household as if they had the same skill level.

For interprovincial wage comparisons we use average manufacturing wages, since it is most likely that a province with a higher average manufacturing wage has higher returns to both unskilled and skilled labor. Using the average wage to represent either skilled or unskilled labor is problematic, since the skill composition of the labor force may vary in some regions due to the relative immobility of unskilled labor. For example, when coastal provinces experience faster technical progress than inland provinces, not only do unskilled wages in inland provinces decrease, but these regions also become more skill-scarce. So our estimate of the effect of coastal growth on average inland income may be biased upward -- albeit with the correct sign. Annual data on the quintile distribution of disposable income and average manufacturing wages come from provincial Statistical Yearbooks (1995-2005).

We have two equations to estimate:

$$
\begin{aligned}
& \ln G_{j t}=\beta_{1} \ln z_{j t}+\beta_{2} \ln \left(H_{j t} / L_{j t}\right)+\beta_{3} \ln X_{j t}^{1} \\
& \ln W_{j t}=\gamma_{1} \ln z_{j t}+\gamma_{2} \ln \left(H_{j t} / L_{j t}\right)+\gamma_{3} \ln X_{j t}^{2}
\end{aligned}
$$

where $H_{j t} / L_{j t}$ is relative skill stock, or the ratio of skilled to unskilled workers at time $\mathrm{t}$ in province $\mathrm{j}$. $X_{j t}$ represents all other variables taken into account. Following Barro and Lee (2000), we define skilled workers as having completed at least college education; all others are classed as unskilled. Data on the composition of employment by educational attainment is from the China Labor Statistical Yearbook (1998-2005). From the model, we expect $\beta_{1}, \beta_{2}, \gamma_{1}$ and $\gamma_{2}$ to be positive.

On the other hand, $z_{j t}$ itself is also function of technology level and variables such as FDI inflow:

$$
\ln z_{j t}=\lambda_{1} \ln P_{j t}+\lambda_{2} \ln X_{j t}^{3}
$$


where $P_{j t}$ is technology level of province $\mathrm{j}$ at time $\mathrm{t}$, and is calculated by dividing total value added by total employment (China Industry Economy Statistical Yearbook 1994-2006). $X_{j t}^{3}$ includes FDI inflows as a percentage of GDP, and arable land per capita. The former represents technology spillover from advanced countries, while the latter can be used to control for natural resources. Resource abundance in a region makes it cheap to produce agricultural and other primary products; other things equal, therefore, its skill intensity of exports should be low. In regressions we lag FDI once, to allow for delays between new capital installation and its impact on production and exports. This also resolves a potential endogeneity problem. Data for these two variables are from provincial Statistical Yearbooks.

Provincial commodity export data are also from provincial Statistical Yearbooks (1993-2005), and the Yearbook of China's Foreign Economic Relations and Trade (1992-2006). At this highly aggregated level (2-digit HS), there is no clear-cut $z_{j t}$ above which a province supplies no exports. Instead, we use the skill-intensity of exports as a proxy. Because an increase in z shifts the economy's export share towards more skill-intensive goods, $\hat{z}_{j t}=\int_{0}^{1} \int_{0}^{z} x_{j t}(z) d z d x$. Using UN classifications, we sort industries into 4 groups by skill intensity (Coxhead and Li 2008, and see appendix table A-1). Then the corresponding provincial export data are classified accordingly. For each province, we define the skill-intensity of its exports in each year as the value of its high-skill exports divided by the value of its total exports. Table 1 gives summary statistics of this variable and others to be used in regression analysis.

\section{INSERT TABLE 1 HERE}

Unit roots in panel data can dramatically affect the asymptotic properties of regression estimates and test statistics (Levin and Lin 1992; Im et al. 2003; Levin et al. 2002; Maddala and Wu 1999). This problem may apply to the wage and income variables (export skill intensity and the Gini coefficient lie in the interval $[0,1]$ and so are automatically stationary). Prior to estimation, we perform Levin-Lin-Chu 
panel data unit root tests on these variables. The tests reject the null of nonstationarity when a first order lag is allowed (see appendix for details). When no lag is included, we cannot reject the null hypothesis that the average manufacturing wage has a unit root. We address this problem in estimation by adding a one-period lagged dependent variable.

Results

First, we confirm that faster technical progress leads to an increase in the sophistication of exports. Column 1 of Table 2 displays province fixed-effect (FE) estimates of equation 11. The coefficient on the technology variable is highly significant and shows that a $1 \%$ increase in technical progress leads to a 0.204\% increase in the skill intensity of exports. The elasticity of export skill intensity with respect to FDI is 0.107. Arable land per capita has a significant negative effect on the dependent variable (-0.54), suggesting that provincial exports follow comparative advantage. The random effects (RE) results (column 2), are very similar to the fixed effects, and this is confirmed by a Hausman test.

\section{INSERT TABLE 2 HERE}

Learning-by-exporting arguments hold that productivity in exporting firms can be improved over time, either because FDI transfers technology to firms that introduce new export products, or because the possibility of selling in export markets stimulates firms to improve their own capabilities (Westphal 2002). Thus the lagged skill intensity of exports may be a determinant of skill intensity in the current stage, which introduces a dynamic element. We therefore implement an AR(1) specification in the disturbance terms. The FE and RE results are reported in columns 3 and 4 . The AR(1) specification makes RE results more reliable, so even though the Hausman test rejects RE in favor of FE, we discuss the RE results. In these, the technology, FDI and natural resource variables retain their significance at $1 \%$, and their magnitudes are comparable with those obtained in the static model.

Another means to deal with dynamics is to include a lagged dependent variable among the regressors, so we have $y_{i t}=\alpha y_{i t-1}+x_{i t}^{\prime} \beta+\mu_{i}+e_{i t}$. In this case, however, the FE estimator is inconsistent 
because the sample mean of $y_{i t-1}$ is correlated with that of $e_{i t}$. One solution is to combine first differencing with IV, i.e., $\Delta y_{i t}=\alpha \Delta y_{i t-1}+\Delta x_{i t}^{\prime} \beta+\Delta e_{i t}$, using $y_{i t-2}$ as an instrument for $\Delta y_{i t-1}$ (Anderson and Hsiao 1981). A frequently preferred alternative is the Arellano-Bond (A-B) estimator (Wooldridge 2001: 304). The A-B estimates are shown in Table 2, column 5, and the pooled IV model in first differences in column 6. These differ somewhat from the AR(1) results. The natural resource variable loses significance, and the technology variable is significant only in the A-B model, with a smaller elasticity (0.063). The FDI variable retains a high level of significance, however, and its elasticity increases somewhat, to 0.259 in the A-B estimates and 0.176 in the IV estimates.

We next turn to inequality, using provincial Gini coefficients as discussed above. We want to test whether greater skill-intensity of exports is associated with higher within-province inequality. The first two columns of Table 3 show estimates of Eq. (10.a). The estimated coefficient on export skill intensity is positive as expected. It predicts that a $1 \%$ higher skilled export share increases the intra-provincial Gini by $0.361 \%$. When an economy concentrates its production and exports on skill-intensive products, skilled labor demand growth exceeds that for unskilled labor. The skill stock variable is also positive (0.108). In these regressions we also include the GDP share of government expenditure as a control for institutional (i.e. non-market) influences on inequality. Until very recently China’s non-military public expenditures were focused almost exclusively on growth, rather than on safety nets or redistributive programs. Public investments in infrastructure largely supported coast-based investments in tradable industries, thus complementing FDI and trade-based sources of growth. The government spending share has an estimated elasticity of 0.262 , indicating that other things equal, the distributional impact of such expenditure has been regressive. Of course, this says nothing about its impact on absolute well-being.

\section{INSERT TABLE 3 HERE}

We also address dynamics. Columns 3 and 4 of Table 3 show AR(1) estimates; these are similar to those in columns 1 and 2. However, the first-differencing and A-B estimates tell a different story. In 
the first-differenced regression neither the human capital nor the public spending variables are significant. In the A-B estimates, human capital is weakly significant with an elasticity of 0.162. But in both cases, the skill intensity of exports remains significant, with elasticity values of 0.629 and 0.290 in the first-differenced and A-B regressions, respectively.

Our model (and the Chinese reality) is of limited labor mobility in response to changing labor demand, and in particular, of greater mobility among skilled than unskilled workers. Thus trade-related changes such as in the skills composition of exports could affect both intra-provincial inequality in other regions, and also inter-regional inequality. We now address both of these issues.

Does an increase in skilled labor demand in one region raise inequality in others? In Table 4, we re-estimate the inequality model on coastal and inland data subsets. In Proposition 3 we hypothesized that a rise in the skill-intensity of exports in one region will attract relatively more skilled than unskilled workers from others, thereby raising the wage premium. To test this, we include variables for the average export skill intensity of provinces in coastal and inland regions in the inequality regressions for the inland and coastal regions, respectively. These variables are robustly positive in all models, so we reject the hypothesis of no inter-provincial effects from inter-regional productivity changes.

\section{INSERT TABLE 4 HERE}

Finally, we examine interregional inequality. The two dependent variables available for this purpose are the average manufacturing wage and the income share of the lowest $20 \%$ of the income distribution in each province. In the first four columns of Table 5 we see that in both specifications, the skill-intensity of coastal region exports has a negative effect on average inland wages. The elasticity (in the A-B model) is -0.041 , meaning that a $1 \%$ increase in coastal export skill intensity leads to a $0.04 \%$ reduction in inland manufacturing wages. Conversely, higher skill-intensity of inland exports reduces the coastal average wage (the elasticity is -0.013). These results support our prediction that rapid 
technical progress (and therefore higher skill-intensity of exports) in one region has a negative effect on average wages in other locations within the same skilled labor market.

\section{INSERT TABLE 5 HERE}

Finally, as a proxy for the incomes of the poor we use disposable income per worker in the bottom $20 \%$ of the provincial wealth distribution. Columns 5-8 in Table 5 show first that higher skillintensity of coastal exports is associated with lower incomes of the poor in inland, and second that higher skill-intensity of inland exports has a negative effect on the incomes of the coastal region's poor. A 1\% increase in the skill intensity of exports from an average coastal province is associated with a 0.56\% decrease in the incomes of the poor in inland provinces. On the other hand, higher export skill intensity in inland provinces lowers the incomes of the poor in coastal areas with an elasticity of -0.693 . These results imply a rather elastic response of incomes of the poor to a change in the composition of exports from other regions. In the presence of restrictions on the interprovincial mobility of low-skill workers, growth in one part of the country may actually impose welfare costs on other parts.

In summary, the estimates confirm our prediction that technical progress shifts export shares towards more skill-intensive goods. In turn, this shift increases intra-province inequality and the provincial average wage. These results mean that technical progress contributes to rising inequality. Also, as predicted, there are interactions between dynamic and lagging regions that may also affect both intra- and inter-province inequality and the income of the poor in each region.

\section{CONCLUSION}

Many economists now maintain that greater openness to trade in developing economies is associated with higher inequality, a view sharply at odds with Heckscher-Ohlin predictions. Analysis of this issue is complicated by market imperfections, specifically those that inhibit factor mobility and cause differential rates of technical progress, since these are also sources of spatial inequality. Our theoretical and econometric analyses both show how interactions between factor mobility limitations and different 
regional rates of technical progress can explain the evolution of inequality in response to trade and FDI. As favored regions benefit more from globalization, they drain skilled workers from less favored areas. In a dynamic sense, the latter lag further behind; average income growth in favored regions is faster. Moreover, unbalanced regional growth may even exert downward pressure on the absolute incomes of unskilled and immobile workers in disadvantaged areas.

It is often observed that exports are positively correlated with economic growth, but that not all forms of export are equal in this respect. Hausmann et al. (2007) show that specialization in higher skillintensity exports leads to faster growth, and that policies that foster skills upgrading in exports have positive growth effects. We have found that in a heterogeneous economy with some labor immobility, high-skill export growth may worsen both interregional and intraregional inequality. Therefore, the aggregate growth effect observed in the literature is in fact a net gain, in which rapid, export-driven expansion in one region of the economy masks slower growth or even contractions in other regions.

Finally, while space limits prevent a detailed policy discussion, it is important to recall that governments also contribute to changes in regional inequality. In order to maximize aggregate growth possibilities, government may prefer to allocate public investments mainly in rapidly growing regions. But with partial labor immobility this will likely exacerbate interregional inequality—and political discontent. The mismatch in China between coast-intensive capital investments and an inland-intensive (and only partially mobile) labor force is also a source of economic inefficiency, and thus a drag on aggregate growth. Since 2000, the Chinese government has responded to these domestic tensions with a massive campaign of public-sector investment, business subsidies, and income tax breaks directed at inland provinces. This so-called "Go West” campaign is a belated attempt to equalize regional rates of output and employment growth and thus to close the development gap. Given the country’s geography, however, it seems likely that coastal locations will continue to offer higher returns on trade-oriented 
private capital investments, and thus that state-funded redistributive measures are clearly second-best relative to policy reforms that liberalize the movement of workers from inland to coast.

\section{REFERENCES}

Anderson, T.W, and Cheng Hsiao. 1981. "Estimation of dynamic models with error components." J. Amer. Stat. Assn. 76: 589-606.

Barro, Robert, and Jong-Wha Lee. 2000. "International data on educational attainment updates and implications.” NBER Working Papers No.7911.

Candelaria, Christopher; Mary Daly, and Galina Hale. 2009. "Beyond Kuznets: persistent regional inequality in China," Working Paper Series 2009-07, Federal Reserve Bank of San Francisco.

Choi, In. 2001. “Unit root tests for panel data.” J. Int. Money \& Banking 20: 249-272.

Coxhead, Ian, and Muqun Li. 2008. "Prospects for skills-based exports in resource-rich developing economies: Indonesia in comparative perspective.” Bull. Indon. Econ. Stud. 44(2): 199-228.

Dixit, Avinash, and Victor Norman. 1980. Theory of International Trade: A Dual General Equilibrium Approach. Cambridge: Cambridge University Press.

Dornbusch, Rudiger; Stanley Fischer, and Paul Samuelson. 1980. "Heckscher-Ohlin trade theory with a continuum of goods.” Quarterly J. Econ. 95: 203-204.

Feenstra, Robert, and Gordon Hanson. 1996. “Globalization, outsourcing, and wage inequality.” Amer. Econ. Rev. 86: 240-245.

Feenstra, Robert, and Gordon Hanson. 2001. “Global production sharing and rising inequality: A survey of trade and wages.” in K. Choi and J. Harrigan (eds.), Handbook of International Trade, Malden: Blackwell.

Fujita, Masahisa; Paul Krugman, and Anthony Venables. 1999. The Spatial Economy: Cities, Regions and International Trade. Cambridge: MIT Press.

Goldberg, Pinelopi, and Nina Pavcnik. 2004. “Trade, inequality, and poverty: What do we know? 
evidence from recent trade liberalization episodes in developing countries.” NBER Working Paper No.10539.

Grossman, Gene, and Elhanan. Helpman. 1991. “Quality ladders and product cycles.” Q. J. Econ. 106: 557-586.

Hale, Galina, and Cheryl. Long. 2008. “Did foreign direct investment put an upward pressure on wages in China?” Federal Reserve Bank of San Francisco Working Papers No. 2006-25.

Hanson, Gordon. 2004. "What has happened to wages in Mexico since NAFTA?" in Antoni Estevadeordal, Dani Rodrick, Alan Taylor and Andres Velasco, eds., FTAA and Beyond: Prospects for Integration in the Americas. Cambridge, MA: Harvard University Press.

Hanson, Gordon, and Ann Harrison. 1995. “Trade, technology, and wage inequality.” NBER WP No. 5110.

Hausmann, Ricardo; Jason Hwang, and Dani Rodrik. 2007. “What you export matters.” J. Econ. Growth 12: 1-25.

Im, Kyung; Pesaran Hashem, and Yongcheol Shin. 2003. “Testing for unit roots in heterogeneous panels.” J. Econometrics 115: 53-74.

Jian, Tianlun; Jeffrey Sachs, and Andrew Warner. 1996. "Trends in regional inequality in China.” NBER WP No.5412.

Knight, John, and Lina Song. 2003. “Increasing urban wage inequality in China: Extent, elements and evaluation.” Econ. of Transition 11: 597-619.

Krugman, Paul. 1991. “Increasing returns and economic geography.” J. Pol. Econ. 99: 483-499.

Krugman, Paul, and Anthony Venables. 1995. “Globalization and the inequality of nations.” Quarterly J. Econ. 60: 857-880.

Levin, Andrew, and Chien-Fu Lin. 1992. "Unit root tests in panel data: Asymptotic and finite-sample properties.” UCSD Working Paper No. 92-23. 
Levin, Andrew; Chien-Fu Lin, and James Chu. 2002. "Unit root tests in panel data: Asymptotics and finite-sample properties.” J. Econometrics 108: 1-24.

Li, Muqun, and Ian Coxhead, 2009. “Trade, technology and inequality in a developing country: theory and evidence from China,” University of Wisconsin-Madison, Department of Agricultural and Applied Economics, Staff Papers No. 539.

Maddala, G S, and Shaowen Wu. 1999. “A comparative study of unit root tests with panel data and a new simple test.” Oxford Bull. Econ. Stat. 61: 631-52.

Monfort, Philippe, and Tanguy van Ypersele. 2003. “Integration, regional agglomeration and international trade.” CEPR Discussion Paper No.3752.

Park, Albert; Xiaoqing Song, Junsen Zhang, and Yaohui Zhao. 2003. “The growth of wage inequality in urban China, 1988 to 1999.” Working Paper.

Rivera-Batiz, Luis, and Paul Romer. 1991. “International trade with endogenous technological change.” Eur. Econ. Rev. 35: 971-1001.

Robbins, Donald. 1996. "Evidence on trade and wages in the developing world.” OECD Development Centre Technical Papers, No. 119.

Vernon, Raymond, 1966. “International investment and international trade in the product cycle.” Q. J. Econ. 80: 190-207.

Wan, Guanghua, and Yin Zhang. 2008. “Explaining the Poverty Difference between Inland and Costal China: A Regression-based Decomposition Approach” Review of Development Economics. 12(2): 455467.

Wang, Qingbin, and Guanming Shi. 2007. "Economic growth and income inequality in the transition toward a market economy: China's experience and policy implications.” in Matt Holt and Jean-Paul Chavas (eds.): Essays in the Honor of Stanley R. Johnson. Berkeley, Berkeley Electronic Press.

Westphal, Larry. 2002. “Technology strategies for economic development in a fast changing global 
economy.” Econ. of Innovation and New Technology 11: 275-320.

Wood, Adrian. 1995. “How trade hurts unskilled workers.” J. Econ. Persp. 9: 57-80.

Wooldridge, Jeffrey. 2002. Econometric Analysis of Cross Section and Panel Data. The MIT Press.

Zhang, Xiaobo, and Kevin Zhang. 2003. "How does globalisation affect regional inequality within a developing country? Evidence from China.” J. Dev. Stud. 39: 47-67.

Zhu, Chun, and Daniel. Trefler. 2005. "Trade and inequality in developing countries: A general equilibrium analysis.” J. Int. Econ. 65: 21-48. 


\begin{tabular}{llrrrrrr}
\hline \multicolumn{1}{c}{ Variable } & \multicolumn{1}{c}{ Unit } & Mean & Median & Std. Dev & Min & Max & Obs \\
& & & & & & & \\
\hline FDI & \% of GDP & 7.800 & 3.070 & 11.792 & 0.326 & 77.100 & 275 \\
Public Spending & share of GDP & 0.156 & 0.146 & 0.052 & 0.074 & 0.500 & 339 \\
Skill intensity of exports & & 0.093 & 0.060 & 0.090 & 0.004 & 0.532 & 339 \\
Human capital & \% of labor force & 6.004 & 5.070 & 4.704 & 0.000 & 30.940 & 309 \\
Arable land & ha /person & 0.101 & 0.075 & 0.069 & 0.015 & 0.321 & 355 \\
Gini Coefficient & & 0.225 & 0.218 & 0.037 & 0.144 & 0.360 & 208 \\
Income of the poor & RMB yuan & 7522 & 6668 & 2760 & 3775 & 18428 & 207 \\
Manufacturing wage & RMB yuan & 9238 & 8364 & 4188 & 3611 & 29743 & 330 \\
Value added per worker & RMB yuan & 58426 & 47651 & 38127 & 9864 & 243447 & 271 \\
\hline
\end{tabular}

Table 1: Summary statistics of key variables

\begin{tabular}{|c|c|c|c|c|c|c|}
\hline \multirow{3}{*}{$\begin{array}{l}\text { Dependent variable } \\
\text { Method }\end{array}$} & \multicolumn{6}{|c|}{ Skill Intensity of Exports } \\
\hline & \multirow[b]{2}{*}{$\mathrm{FE}$} & \multirow[b]{2}{*}{$\mathrm{RE}$} & \multicolumn{2}{|c|}{ AR(1) } & \multirow{2}{*}{$\begin{array}{l}\text { Arellano- } \\
\text { Bond }\end{array}$} & \multirow{2}{*}{$\begin{array}{c}\text { First } \\
\text { differencing }\end{array}$} \\
\hline & & & $\mathrm{FE}$ & $\mathrm{RE}$ & & \\
\hline $\begin{array}{l}\text { Lagged skill- } \\
\text { intensity of exports }\end{array}$ & & & & & $\begin{array}{l}0.132 * * \\
(0.0669)\end{array}$ & $\begin{array}{c}0.889 \\
(0.7566)\end{array}$ \\
\hline Technology level & $\begin{array}{l}0.204^{* * *} \\
(0.0442)\end{array}$ & $\begin{array}{c}0.187 * * * \\
(0.0404)\end{array}$ & $\begin{array}{c}0.104^{*} \\
(0.0595)\end{array}$ & $\begin{array}{c}0.192 * * * \\
(0.0465)\end{array}$ & $\begin{array}{c}0.063^{*} \\
(0.0360)\end{array}$ & $\begin{array}{c}0.106 \\
(0.0798)\end{array}$ \\
\hline FDI & $\begin{array}{l}0.107^{* *} \\
(0.0494)\end{array}$ & $\begin{array}{c}0.138^{* * *} \\
(0.0452)\end{array}$ & $\begin{array}{c}0.128^{*} \\
(0.0725)\end{array}$ & $\begin{array}{c}0.144 * * * \\
(0.0472)\end{array}$ & $\begin{array}{l}0.259 * * * \\
(0.0595)\end{array}$ & $\begin{array}{c}0.176^{* * *} \\
(0.0605)\end{array}$ \\
\hline Arable land per capita & $\begin{array}{l}-0.544 * * \\
(0.2772)\end{array}$ & $\begin{array}{c}-0.783 * * * \\
(0.1519)\end{array}$ & $\begin{array}{c}-0.014 \\
(0.3695)\end{array}$ & $\begin{array}{l}-0.780 * * * \\
(0.1456)\end{array}$ & $\begin{array}{c}0.159 \\
(0.3291)\end{array}$ & $\begin{array}{c}-0.152 \\
(0.3533)\end{array}$ \\
\hline \multicolumn{7}{|l|}{ Hausman test } \\
\hline Chi-square & \multicolumn{2}{|c|}{2.40} & \multicolumn{2}{|c|}{28.45} & & \\
\hline Observations & 290 & 290 & 261 & 290 & 254 & 254 \\
\hline Groups & 29 & 29 & 29 & 29 & 29 & \\
\hline Adj R-square: & & & & & & 0.0459 \\
\hline Within & 0.1878 & 0.1849 & 0.0381 & 0.1850 & & \\
\hline Between & 0.6002 & 0.5969 & 0.4660 & 0.5982 & & \\
\hline Overall & 0.5611 & 0.5636 & 0.4131 & 0.5652 & & \\
\hline
\end{tabular}

Standard errors in parentheses

* significant at $10 \%$; ** significant at $5 \%$; *** significant at $1 \%$

Table 2: Estimation results: skill intensity of exports 


\begin{tabular}{lcccccc}
\hline Dependent variable & \multicolumn{5}{c}{ Gini Coefficient } \\
\hline Method & \multicolumn{7}{c}{ AR(1) } & $\begin{array}{c}\text { First } \\
\text { difference }\end{array}$ & $\begin{array}{c}\text { Arellano- } \\
\text { Bond }\end{array}$ \\
\hline Public spending & $0.262^{* * *}$ & $0.146^{* *}$ & $0.270^{* * *}$ & $0.140^{* *}$ & 0.166 & 0.162 \\
& $(0.0772)$ & $(0.0573)$ & $(0.0975)$ & $(0.0567)$ & $(0.1319)$ & $(0.1931)$ \\
Skill stock & $0.108^{* * *}$ & $0.084^{* * *}$ & $0.089^{* *}$ & $0.080^{* * *}$ & 0.004 & $0.097^{*}$ \\
& $(0.0339)$ & $(0.0245)$ & $(0.0403)$ & $(0.0243)$ & $(0.0398)$ & $(0.0506)$ \\
Lagged Gini & & & & & 0.378 & $-0.352^{* * *}$ \\
$\quad$ coefficient & & & & & $(0.0803)$ & $(0.1359)$ \\
Skill intensity & $0.361^{* * *}$ & 0.057 & $0.362^{* * *}$ & 0.055 & $0.629 * * *$ & $0.290^{*}$ \\
$\quad$ of exports & $(0.0938)$ & $(0.0353)$ & $(0.1155)$ & $(0.0346)$ & $(0.1937)$ & $(0.1531)$ \\
Hausman test & & & & & & 153 \\
Chi-square & 89.93 & & 25.65 & & & 28 \\
Observations & 213 & 213 & 184 & 213 & 153 & \\
Groups & 29 & 29 & 29 & 29 & & \\
Adj R-square: & & & & & 0.1473 & \\
Within & 0.3560 & 0.3298 & 0.2659 & 3297 & & \\
Between & 0.0099 & 0.0417 & 0.0243 & 0.0418 & & \\
Overall & 0.0251 & 0.038 & 0.0084 & 0.038 & & \\
\hline \hline
\end{tabular}

Standard error in brackets

* significant at $10 \%$; ** significant at $5 \%$; *** significant at $1 \%$

Table 3: Estimation results: Gini coefficient (whole sample) 


\begin{tabular}{|c|c|c|c|c|c|c|c|c|}
\hline \multirow{3}{*}{$\begin{array}{l}\text { Dependent variable } \\
\text { Method } \\
\end{array}$} & \multicolumn{8}{|c|}{ Gini Coefficient } \\
\hline & \multirow{2}{*}{$\frac{\mathrm{FE}}{\text { Inland }}$} & \multirow{2}{*}{$\frac{\text { FE }}{\text { Coast }}$} & \multicolumn{2}{|c|}{ FE AR(1) } & \multicolumn{2}{|c|}{ First differencing } & \multicolumn{2}{|c|}{ Arellano-Bond } \\
\hline & & & Inland & Coast & Inland & Coast & Inland & Coast \\
\hline \multirow[t]{2}{*}{ Public spending } & $0.193^{* *}$ & 0.062 & 0.199 & 0.080 & -0.139 & $-0.741 * * *$ & $=0.352$ & -0.083 \\
\hline & $(0.0893)$ & $(0.1347)$ & $(0.1257)$ & $(0.1404)$ & $(0.1562)$ & $(0.1804)$ & $(0.2925)$ & (0.2069) \\
\hline \multirow[t]{2}{*}{ Skill stock } & 0.039 & $0.089 *$ & -0.034 & $0.099 * * *$ & -0.284 & 0.075 & $1.350 * *$ & 0.208 \\
\hline & $(0.0464)$ & $(0.0454)$ & $(0.0466)$ & $(0.0461)$ & $(0.3301)$ & $(0.0673)$ & $(0.4437)$ & $(0.0991)$ \\
\hline Coastal skill- & $0.504^{* * *}$ & & $0.555^{* * *}$ & & $1.433^{*}$ & & $1.682 * *$ & \\
\hline intensity of exports & $(0.1373)$ & & $(0.2116)$ & & $(0.7332)$ & & $(0.7574)$ & \\
\hline Inland skill- & & $0.767 * * *$ & & $0.848^{* * *}$ & & $0.346^{* *}$ & & $1.016^{* * *}$ \\
\hline intensity of exports & & $(0.1460)$ & & $(0.1572)$ & & $(0.1721)$ & & $(0.2331)$ \\
\hline Lagged Gini & & & & & -0.112 & 0.050 & $-0.303^{* *}$ & $-0.728 * * *$ \\
\hline coefficient & & & & & (0.1216 & $(0.1245)$ & $(0.1275)$ & $(0.1233)$ \\
\hline Skill intensity & -0.040 & 0.132 & 0.026 & $0.238 * * *$ & 0.172 & 0.467 & -0.110 & $0.486^{*}$ \\
\hline of exports & $(0.0315)$ & $(0.1058)$ & $(0.0370)$ & $(0.1156)$ & $(0.1914)$ & $(0.5075)$ & $(0.3300)$ & $(0.2638)$ \\
\hline Observations & 125 & 88 & 108 & 76 & 90 & 63 & 90 & 63 \\
\hline Groups & 17 & 12 & 17 & 12 & & & 16 & 12 \\
\hline Adj R-square: & & & & & 0.0686 & 0.2157 & & \\
\hline Within & 0.3363 & 0.6126 & 0.1616 & 0.6060 & & & & \\
\hline Between & 0.0429 & 0.0005 & 0.0418 & 0.0033 & & & & \\
\hline Overall & 0.0813 & 0.1725 & 0.0207 & 0.0778 & & & & \\
\hline
\end{tabular}

Standard error in brackets

* significant at $10 \%$; ** significant at $5 \%$; *** significant at $1 \%$

Table 4 Estimation results: Gini coefficient (by region) 


\begin{tabular}{lccccccccc}
\hline \multirow{2}{*}{ Dependent Variable } & \multicolumn{3}{c}{ Manufacturing wage } & \multicolumn{3}{c}{ Bottom 20\% income } \\
\hline & \multicolumn{1}{c}{ First differencing } & \multicolumn{2}{c}{ Arellano-Bond } & First differencing & Arellano-Bond \\
\hline Method & Inland & Coast & Inland & Coast & Inland & Coast & Inland & Coast \\
\hline Public spending & -0.014 & 0.080 & -0.008 & 0.002 & $-0.385^{* *}$ & 0.104 & $-0.347^{*}$ & 0.203 \\
& $(0.0591)$ & $(0.0634)$ & $(0.0424)$ & $(0.0455)$ & $(0.1825)$ & $(0.2088)$ & $(0.1453)$ & $(0.1440)$ \\
Skill stock & 0.022 & $0.587^{* * *}$ & $0.018^{*}$ & 0.023 & -0.120 & -0.080 & 0.022 & 0.005 \\
& $(0.0185)$ & $(0.1430)$ & $(0.0107)$ & $(0.0199)$ & $(0.3401)$ & $(0.0764)$ & $(0.0543)$ & $(0.0602)$ \\
Coast skill- & $-0.387^{* *}$ & & $-0.041^{* *}$ & & 0.512 & & $-0.559^{*}$ \\
intensity of exports & $(0.1561)$ & & $(0.0191)$ & & $(0.6003)$ & & $(0.2961)$ \\
Inland skill- & & $-0.025^{*}$ & & $-0.013^{*}$ & & $-0.811^{* * *}$ & $-0.693^{* * *}$ \\
intensity of exports & & $(0.0127)$ & & $(0.0067)$ & & $(0.1967)$ & $(0.1612)$ \\
Lagged & $0.548^{* * *}$ & $0.943^{* * *}$ & $-0.309^{* * *}$ & $-0.359^{* * *}$ & $0.876^{* * *}$ & $0.895^{* * *}$ & 0.037 & $0.291^{* * *}$ \\
dependent variable & $(0.0917)$ & $(0.1634)$ & $(0.0785)$ & $(0.0959)$ & $(0.1047)$ & $(0.0665)$ & $(0.2339)$ & $(0.1030)$ \\
Skill intensity & $0.300^{* * *}$ & $0.587^{* * *}$ & $0.042^{*}$ & $0.014^{*}$ & -0.120 & 0.451 & 0.300 & $0.397^{* * *}$ \\
$\quad$ of exports & $(0.1033)$ & $(0.1430)$ & $(0.0235)$ & $(0.0059)$ & $(0.3401)$ & $(0.5757)$ & $(0.2367)$ & $(0.1070)$ \\
Observations & 153 & 108 & 153 & 108 & 90 & 63 & 90 & 63 \\
Groups & & & 16 & 12 & & & 16 & 12 \\
Adjusted R & 0.7527 & 0.7691 & & & 0.4883 & 0.7733 & & \\
\hline \hline
\end{tabular}

Standard error in brackets

* significant at $10 \%$; ** significant at $5 \%$; *** significant at $1 \%$

Table 5: Estimation results: wages and poverty 